\section{Continuous infusion of frusemide in refractory oedema}

Frusemide is a potent loop diuretic with an impressive dose-response relationship over a wide dose range. Nevertheless, probably because of concern over possible toxicity, ${ }^{1}$ the attainment of an effective dose may be delayed in patients with oedema refractory to conventional dosing. We report here the frequency with which high-dose frusemide was prescribed in a group of medical inpatients and then describe a small series of patients who were given continuous infusion of frusemide using a constant infusion pump.

\section{Patients, methods, and results}

During 1973 a study of prescribing habits was carried out in the medical division of Glasgow Royal Infirmary, ${ }^{2}$ Details of drug use were recorded in 5288 consecutive admissions. A total of $1292(24 \%)$ patients received frusemide, the mean daily dose received being up to $40 \mathrm{mg}$ in $58 \%$ of recipients, $41-240 \mathrm{mg}$ in $30 \%$, and over $240 \mathrm{mg}$ in $12 \%$. Patients receiving up to $40 \mathrm{mg}$ daily stayed on average 13 (SD 8) days in hospital compared with 16 (SD 9) days for those receiving over $240 \mathrm{mg}$ daily. One factor that partially explained the increase in length of stay in the high-dose group was the time taken to attain an effective dose of frusemide. In view of this 10 patients (five men, five women) suffering from congestive cardiac failure who had failed to respond with a diuresis to $120 \mathrm{mg}$ frusemide orally were given a constant infusion of frusemide intravenously. The average age of the patients was $67 \cdot 5$ years (range $60-75$ years).

All patients attained satisfactory diuresis, but there was no correlation between the urinary output or urinary potassium or sodium concentration and the rate of frusemide infusion (table). The average urine volume during infusion ( $t S E$ of mean) was $3.5 \pm 0.8 \mathrm{ml} / \mathrm{min}$, average urinary sodium concentration $80 \pm 9.8 \mathrm{mmol}(\mathrm{mEq}) / \mathrm{l}$ and urinary potassium concentration $21 \pm 2.4 \mathrm{mmol}(\mathrm{mEq}) / 1$. Preinfusion data were available for five of the subjects and in all five there were substantial increases in peak minute urine volume ( $1 \mathrm{ml}$ before, $5.1 \mathrm{ml}$ after infusion), urinary sodium excretion rates (58 and $327 \mathrm{mmol} / 12$ hours respectively), and potassium excretion rates (29 and 80 $\mathrm{mmol} / 12$ hours respectively).

The mean admission plasma potassium concentration was $3 \cdot 8 \pm 0 \cdot 1 \mathrm{mmol} /$ and this fell to $3.5+0.2 \mathrm{mmol} / \mathrm{l}$ after completion of the infusion. No patient received supplementary potassium treatment during the study and fou developed hypokalaemia (plasma $\mathrm{K}^{+}<3.5 \mathrm{mmol} / \mathrm{l}$ ); the lowest plasma potassium concentrations were $3 \cdot 0,3 \cdot 1,3 \cdot 2$, and $3 \cdot 4 \mathrm{mmol} / \mathrm{l}$.

No patient developed hyponatraemia, glycosuria, gout, or impaired hearing during the infusion. The mean plasma urate concentrations after the infusion were $412 \pm 23 \mathrm{mmol} / 1(6924 \pm 386 \mathrm{mg} / 100 \mathrm{ml})$.

\section{Comment}

Since an appreciable number of patients with cardiac failure need high-dose frusemide before a diuresis is obtained, with consequent prolongation of their stay in hospital, we assessed the feasibility and safety of administering frusemide in low doses by continuous infusion. All responded to this treatment, the only complication being mild hypokalaemia in those with the greatest urinary outputs, who were not receiving potassium supplements at the time. This method of administration avoids large bolus doses by mouth or by injection, permits a controlled gentle diuresis to occur, and thereby avoids the risk of prostatism in elderly men subject to intensive diuretic treatment. The rate of infusion required varied from 4-16 mg/h and could be increased stepwise until the desired effect was obtained. In the present study plasma frusemide concentrations of $0.5 \mathrm{mg} / 1$ were associated with peak sodium excretion rates of $5.5 \mathrm{mmol} / \mathrm{min}$; this rate was equivalent to that found at plasma concentrations greater than 10 $\mathrm{mg} / \mathrm{l}$ after an $80-\mathrm{mg}$ intravenous dose. ${ }^{3}$ Thus effective diuresis was achieved at blood concentrations considerably below those at which extrarenal effects of frusemide are seen. ${ }^{4}$

1 Greenblatt, D J, et al, American Heart fournal, 1977, 94, 6.

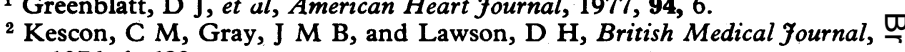
$1976,1,680$.

3 Branch, R A, et al, British fournal of Clinical Pharmacology, 1977, 4, 121.

${ }^{4}$ Rupp, W, Scottish Medical fournal, 1974, 19, suppl p 5.

(Accepted 12 May 1978)

Clinical Pharmacology Service, Glasgow Royal Infirmary, School of Pharmaceutical Science, University of Strathclyde, Glasgow

D H LAWSON, MD, FRCPED, professor

J M B GRAY, MB, BCH, research registrar

D A HENRY, MRCP, registrar

W J TILSTONE, PHD, MRCPATH, lecturer

\section{Cyanoacrylate adhesive for foreign body removal}

We report the use of cyanoacrylate adhesive in removing an impacted $\subseteq$ oesophageal foreign body.

\section{Case report}

A severely mentally retarded 18 -year-old man in an institution was referred to our unit with a one-week history of inability to take solid food. $\vec{\theta}$ He had been admitted on three previous occasions after ingesting foreign bodies, laparotomy being required on one occasion. $\mathrm{He}$ was clinically dehydrated, but had no other abnormal physical signs. Plain radiography showed numerous radio-opaque foreign bodies in his gastrointestinal tract, including one in the upper oesophagus.

Oesophagoscopy under general anaesthesia showed a $4 \mathrm{~cm} \times 3 \mathrm{~cm} \times 3 \mathrm{~cm}$ stone at $20 \mathrm{~cm}$, with a smooth, rounded surface presenting which could not be grasped by any instrument. A 14 FG Foley type catheter with a 25-ml balloon could be passed beyond the stone ${ }^{1}$ using an introducer, but when traction was applied with the balloon inflated the stone merely rotated, 0 allowing the balloon to pass alongside. The surface of the stone was carefully cleaned with methylated spirit. Cyanoacrylate adhesive (Superglue 3,

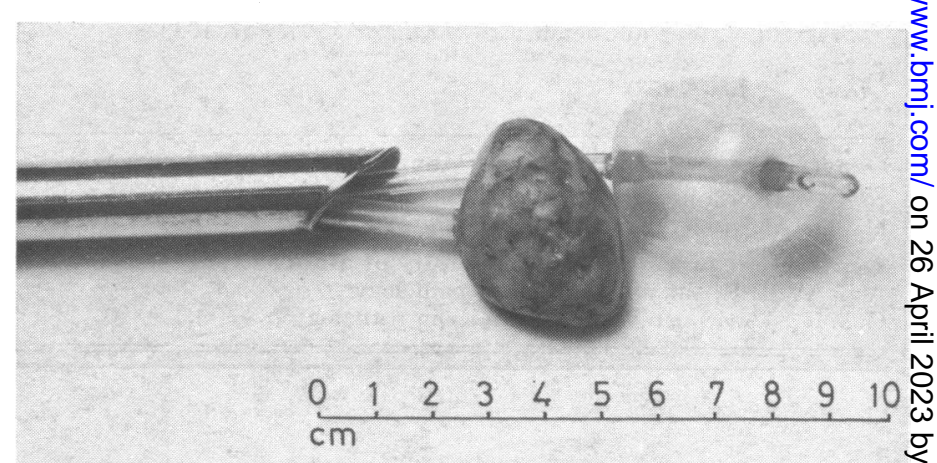

Foreign body attached to rigid plastic tube with cyanoacrylate adhesive, inflated Foley catheter, and pharyngoscope after removal from oesophagus.

Effect of frusemide infusions on urine volume and electrolyte excretion

\begin{tabular}{|c|c|c|c|c|c|c|c|}
\hline $\begin{array}{l}\text { Case } \\
\text { No }\end{array}$ & $\begin{array}{l}\text { Age and } \\
\text { sex }\end{array}$ & $\begin{array}{l}\text { Peak urine } \\
\text { flow } \\
(\mathrm{ml} / \mathrm{min})\end{array}$ & $\begin{array}{c}\text { Frusemide infusion } \\
\text { rate } \\
(\mathbf{m g} / \mathbf{h})\end{array}$ & $\begin{array}{c}\text { Frusemide plasma } \\
\text { concentration } \\
(\mathrm{mg} / \mathrm{l})\end{array}$ & $\begin{array}{l}\text { Urinary sodium } \\
(\mathrm{mmol} / \mathrm{l})\end{array}$ & $\begin{array}{l}\text { Urinary potassium } \\
(\mathrm{mmol} / \mathrm{l})\end{array}$ & $\begin{array}{l}\text { Urine volume } \\
\text { per } 24 \mathrm{~h} \\
\text { (1) }\end{array}$ \\
\hline $\begin{array}{r}1 \\
2 \\
3 \\
4 \\
5 \\
6 \\
7 \\
8 \\
9 \\
10\end{array}$ & $\begin{array}{l}60 \mathrm{M} \\
65 \mathrm{M} \\
60 \mathrm{~F} \\
67 \mathrm{M} \\
73 \mathrm{~F} \\
72 \mathrm{~F} \\
72 \mathrm{~F} \\
62 \mathrm{M} \\
68 \mathrm{~F} \\
75 \mathrm{M}\end{array}$ & $\begin{array}{l}5.2 \\
2.5 \\
9.8 \\
2.5 \\
2.4 \\
2.8 \\
1.6 \\
5.0 \\
1.4 \\
1.9\end{array}$ & $\begin{array}{r}4 \\
5 \\
8 \\
8 \\
8 \\
8 \\
10 \\
10 \\
12 \\
16\end{array}$ & $\begin{array}{l}0.4 \\
0.4 \\
0.7 \\
0.9 \\
0.7 \\
\\
0.8 \\
0.6 \\
0.9\end{array}$ & $\begin{array}{r}112 \\
36 \\
85 \\
34 \\
114 \\
113 \\
59 \\
92 \\
97 \\
60\end{array}$ & $\begin{array}{r}21 \\
9 \\
25 \\
36 \\
22 \\
22 \\
21 \\
10 \\
21 \\
23\end{array}$ & $\begin{array}{r}7 \cdot 5 \\
3 \cdot 6 \\
14 \cdot 1 \\
3 \cdot 6 \\
3.5 \\
4 \cdot 0 \\
2 \cdot 3 \\
7 \cdot 2 \\
2 \cdot 0 \\
2 \cdot 7\end{array}$ \\
\hline
\end{tabular}

